\title{
OPTIMASI PENGGUNAAN HIDROKOLOID TERHADAP PASTA MAKARONI BERBASIS BERAS BERAMILOSA TINGGI
}

\author{
[Hydrocolloid Optimization on Maccaroni Pasta from High Amylose Rice]
}

\author{
Eko Hari Purnomo ${ }^{1) \star}$, Endang Yuli Purwani ${ }^{2)}$, dan Tri Wahyu Sulistyawati ${ }^{1)}$ \\ 1) Departemen Ilmu dan Teknologi Pangan, Fakultas Teknologi Pertanian, Institut Pertanian Bogor, Bogor \\ 2) Balai Besar Penelitian dan Pengembangan Pasca Panen Pertanian, Kementerian Pertanian, Jakarta
}

Diterima 08 Oktober 2015 / Disetujui 28 Desember 2015

\begin{abstract}
Pasta is an extrusion product which is commonly produced from wheat flour. Gluten is key substance of wheat flour that affect quality of pasta, such as low cooking loss, low adhesiveness and firm pasta structure. However, gluten may cause health problem for consumers with celiac disease or gluten intolerance. Rice is safe for celiac disease sufferer, but it is technologically challenging to develop ricebased pasta. The objective of this research was to evaluate the effect of different ratio between xanthan gum and guar gum (2\%) on the physical characteristics of macaroni pasta from rice flour. This research consisted of several steps which include flour milling and characterization, formulation, and final product analysis. The result showed that different ratio of xanthan gum and guar gum had significant effect to cooking loss, adhesiveness, springiness and hue parameters $(P<0.05)$, but it did not give significant effect to water absorbtion, swelling volume, chroma and lightness response $(P>0.05)$. The optimum formula was noodle by hydrocolloid ratio $2 \%$ of xanthan gum and $0 \%$ of guar gum which had desirability value of 0.798 . The selected formula was organoleptically accepted by panelists and containing $9.84 \%$ of water, $1.65 \%$ of ash, $12.05 \%$ of protein, $1.41 \%$ of fat, $75.05 \%$ of carbohydrate, $24.49 \%$ of amylose, also $33.49 \mu \mathrm{m}$ of pore size.
\end{abstract}

keywords: gluten, hydrocolloid, pasta, rice flour

\begin{abstract}
ABSTRAK
Pasta ialah produk ekstrusi yang umumnya terbuat dari tepung gandum. Gluten merupakan komponen utama yang berpengaruh terhadap kualitas pasta seperti parameter cooking loss, kelengketan yang rendah serta struktur yang kokoh. Di sisi lain, gluten dapat menyebabkan gangguan kesehatan bagi penderita celiac disease atau gluten intolerance. Beras merupakan salah satu bahan yang aman dikonsumsi bagi penderita celiac disease, namun secara teknologi cukup menantang untuk mengembangkan pasta berbasis beras. Tujuan dari penelitian ini adalah untuk mengevaluasi pengaruh perbedaan rasio antara xanthan gum dan guar gum (2\%) terhadap karakteristik fisik makaroni pasta dari tepung beras. Penelitian ini terdiri dari beberapa tahap yaitu penepungan dan karakterisasi, formulasi, dan analisis produk akhir. Hasil penelitian menunjukkan bahwa perbedaan rasio antara xanthan gum dan guar gum berpengaruh secara signifikan terhadap parameter cooking loss, kelengketan, springiness dan hue $(P<0,05)$, tetapi tidak memberikan pengaruh yang signifikan terhadap respon daya serap air, pengembangan volume, chroma dan lightness $(P>0,05)$. Formula optimum terpilih yaitu mi dengan rasio penambahan hidrokoloid $2 \%$ xanthan gum dan $0 \%$ guar gum dan memiliki nilai desirability 0,798 Formula terpilih dapat diterima secara organoleptik oleh panelis dan memiliki kadar air $9,84 \%$, abu 1,65\%, protein $12,05 \%$, lemak $1,41 \%$ lemak, karbohidrat $75,05 \%$, amilosa $24,49 \%$, serta memiliki ukuran pori $33,49 \mu \mathrm{m}$.
\end{abstract}

Kata kunci: gluten, hidrokoloid, pasta, tepung beras

\section{PENDAHULUAN}

Pasta sebagai salah satu sumber karbohidrat merupakan jenis produk pangan ekstrusi. Umumnya, pasta terbuat dari tepung terigu dan memiliki parameter kualitas yang lebih baik dibandingkan dengan bahan lain seperti cooking loss rendah, tekstur produk kompak dan kelengketan rendah (Fernandez et al., 2013).

${ }^{*}$ Penulis Korespondensi:

E-mail: ekohari_p@yahoo.com 
Salah satu faktor pembatas terigu sebagai bahan dasar pembuatan makaroni pasta adalah kandungan gluten (terdiri atas glutenin dan gliadin) yang tidak dapat dikonsumsi bagi penderita gluten intolerance atau celiac disease, serta autis. Penderita gluten intolerance tidak dapat menyerap zatzat gizi dari produk yang mengandung gluten akibat malfungsi sistem pencernaan. Keberadaan gluten pada bahan pangan menyebabkan sistem imun memproduksi antibodi untuk melawan gluten, sehingga terjadi kerusakan sel epitelium pada pada usus halus (Mirhosseini et al., 2015). Gluten free diet merupakan solusi bagi orang yang menderita gluten intolerance atau celiac disease, yaitu dengan mengonsumsi sumber pangan selain terigu dan oats (Yalcin dan Basmin, 2008).

Beras menjadi bahan alternatif untuk mengembangkan produk pangan bebas gluten karena aman dikonsumsi bagi konsumen berkebutuhan khusus (Fernandez et al., 2013). Beras dapat membentuk struktur dasar pada pasta makaroni karena keberadaan pati yang menentukan karakteristik produk yang diinginkan (Cabrera-Chavez et al., 2012). Fraksi amilosa dan amilopektin yang terdapat pada pati beras dapat berikatan membentuk matriks pasta. Pati beras dapat membentuk struktur plastis apabila telah mengalami gelatinisasi. Idealnya, pati yang digunakan untuk mengembangkan produk pasta bebas gluten memiliki komposisi amilopektin yang lebih tinggi dibandingkan amilosa (Marti dan Paggani, 2013).

Penggunaan beras sebagai bahan utama dalam pembuatan pasta bebas gluten membutuhkan bahan lain yang dapat membantu pembentukan matriks atau struktur adonan yang kohesif seperti adonan terigu. Penambahan hidrokoloid atau gum pada tepung non gluten dengan konsentrasi 0,5$2,5 \%$ dapat meningkatkan konsistensi di suhu ruang dan firmness pasta, memberi mouthfeel pada produk (Puspasari, 2007; Marti dan Paggani, 2013), serta meningkatkan kecepatan rehidrasi karena kemampuannya dalam mengikat air (Sozer, 2009). Xanthan gum dan guar gum merupakan hidrokoloid komersial untuk ditambahkan dalam proses pembuatan pasta. Penambahan xanthan gum dapat meningkatkan kekokohan dan kekuatan mie (Silva et al., 2013). Penambahan guar gum pada adonan pasta beras menghasilkan adonan yang mudah diproses dan ditangani (Sozer, 2009) dan meningkatkan penerimaan atribut tekstur pada uji sensori (Raina et al., 2005).

Penelitian ini dilakukan dengan tujuan mempelajari pengaruh penggunaaan hidrokoloid sebanyak $2 \%$ serta mendapatkan formula rasio hidrokoloid yang terdiri atas xanthan gum dan guar gum terhadap produk pasta makaroni bebas gluten dari tepung beras. Diharapkan penambahan hidrokoloid pada pasta makaroni bebas gluten dapat memperbaiki karakteristik dari produk, terutama dalam pembentukan tekstur. Optimasi produk pasta dilakukan menggunakan Response Surface Methodology, yaitu D-Optimal mixture design.

\section{BAHAN DAN METODE}

\section{Bahan}

Bahan yang digunakan untuk pembuatan pasta makaroni ialah beras beramilosa tinggi varietas IR42 yang diperoleh dari Karawang, garam Refina (Refined salt), telur ayam lokal, guar gum dan xanthan komersial yang diperoleh dari supplier Jakarta, serta tepung terigu protein tinggi Cakra Kembar' $^{T M}$ (Bogasari, Indonesia).

\section{Penepungan dan karakterisasi}

Persiapan bahan diawali dengan proses penepungan beras menggunakan metode penepungan basah dengan waktu perendaman 8 jam (Prasad et al., 2012) untuk menghasilkan tepung beras dengan ukuran 100 mesh. Karakterisasi tepung yang dilakukan meliputi analisis proksimat (AOAC, 2005) dan kadar amilosa (Faridah et al., 2014).

\section{Formulasi produk}

Produk pasta makaroni dari beras diproduksi dengan menggunakan teknologi ekstrusi dengan prosedur mengacu pada pembuatan produk pasta makaroni bebas gluten (Fernanda et al., 2013; Wahyudi, 2012) dan menggunakan ekstruder pencetak manual. Variabel tetap dalam penelitian mencakup tepung beras, garam, air dan telur, sedangkan hidrokoloid xanthan gum dan guar gum merupakan peubah bebas (disajikan pada Tabel 1).

Tabel 1. Formula pasta makaroni dengan basis $100 \mathrm{~g}$ tepung beras

\begin{tabular}{lc}
\multicolumn{1}{c}{ Bahan } & Jumlah \\
\hline Tepung beras (g) & 100 \\
Garam (\%) & 1,00 \\
Telur ayam (\%) & 40,00 \\
Air (\%) & 40,00 \\
Hidrokoloid (xanthan gum dan guar & 2,00 \\
gum) (\%) & \\
\hline
\end{tabular}

Keterangan: Komponen hidrokoloid merupakan variabel peubah yaitu rasio antara xanthan gum dan guar gum

Kombinasi penggunaan xanthan gum dan guar gum dengan total penambahan $2 \%$ basis tepung beras selanjutnya diinput ke dalam program Design Expert $7.0^{\circledR}$ menghasilkan delapan formula dengan tiga replikasi, seperti dicantumkan pada Tabel 2. Model percobaan yang digunakan yaitu D-optimal Mixture Design untuk melakukan optimasi. Penentuan waktu pemasakan optimum (AACC, 2000) dihitung dari saat hilangnya titik putih pasta setelah ditekan antara dua piringan gelas. 
Tabel 2. Rancangan faktor peubah pada pembuatan formula makaroni beras (menggunakan software Design Expert 7.00®)

\begin{tabular}{ccc}
\hline Formula & $\begin{array}{c}\text { Xanthan Gum } \\
(\%)\end{array}$ & $\begin{array}{c}\text { Guar Gum } \\
(\%)\end{array}$ \\
\hline F1(1) & 0,0 & 2,0 \\
F1(2) & 0,0 & 2,0 \\
F1(3) & 0,0 & 2,0 \\
F2 & 0,3 & 1,7 \\
F3 & 0,5 & 1,5 \\
F4 & 0,8 & 1,2 \\
F5(1) & 1,0 & 1,0 \\
F5(2) & 1,0 & 1,0 \\
F6 & 1,5 & 0,5 \\
F7 & 1,7 & 0,3 \\
F8(1) & 2,0 & 0,0 \\
F8(2) & 2,0 & 0,0 \\
F8(3) & 2,0 & 0,0 \\
\hline
\end{tabular}

\section{Cooking quality}

Kualitas masak ditentukan berdasarkan nilai daya serap air dan cooking loss (Tong et al., 2015). Sebanyak $20 \mathrm{~g}$ sampel pasta dimasak dengan 200 $\mathrm{mL}$ air destilata didasarkan pada waktu pasta terhidrasi sempurna, kemudian pasta matang ditimbang setelah ditiriskan selama 5 menit. Untuk mengukur susut masak (cooking loss) sebanyak 25 $\mathrm{mL}$ air sisa rebusan pasta dikeringkan pada suhu $105^{\circ} \mathrm{C}$ hingga mencapai bobot konstan. Jumlah air yang diserap (daya serap air) dan susut masak (cooking loss) dihitung berdasarkan rumus berikut:

\section{Daya serap air $=$}

$$
\frac{\text { (berat pasta masak-berat pasta mentah) }}{\text { berat pasta mentah }} \times 100
$$

Cooking loss =

$\frac{\text { berat kering residu air rebusan } x(\text { volume pemasakan/25) }}{\text { berat pasta mentah }} \times 100$

\section{Pengembangan volume}

Analisis terhadap pengembangan volume pasta dilakukan dengan mengukur dimensi ketebalan, diameter dan panjang pasta pada lima titik yang dipilih acak sebanyak tiga kali ulangan menggunakan mikrometer sekrup (Nsk, Jepang spec. 870-1950). Pengembangan volume pasta diperoleh dari pers entase volume pasta masak relatif terhadap volume pasta mentah.

\section{Analisis tekstur}

Analisis tekstur dilakukan menggunakan alat Texture Analyzer Pro CT V1.2 Build 9 (Brokfield Engeneering Labs Inc, USA) dengan probe TA4/ 1000 (bentuk silinder dan ukuran $38,1 \mathrm{~mm}$ ) serta fixture TA-BT-KIT untuk cooked pasta. Alat di setting dengan parameter pre test speed $2 \mathrm{~mm} / \mathrm{s}$, test speed $0,5 \mathrm{~mm} / \mathrm{s}$, trigger load $4,5 \mathrm{~g}$ dan persentase deformasi $75 \%$. Setiap sampel diuji dengan lima kali ulangan. Parameter tekstur yang diukur untuk optimasi formula produk adalah springiness dan adhesiveness.

\section{Analisis warna}

Analisis warna dilakukan menggunakan Chromameter Minolta CR 300 (Osaka, Jepang). Parameter warna $\left(L^{*}, a^{*}, b^{*}\right)$ diukur untuk menentukan intensitas warna pada pasta masak. Setiap pengukuran sampel dilakukan terhadap tiga titik secara acak. Nilai hue dihitung dengan rumus sebagai berikut:

$$
\text { Hue }=\tan ^{-1} \frac{\mathrm{b}^{*}}{\mathrm{a}^{*}} \quad \text { Chroma }=\sqrt{a *^{2}+b *^{2}}
$$

Keterangan: (Herrero dan Frutos, 2015)

\section{Optimasi formula}

Proses optimasi diawali dengan melakukan analisis sidik ragam dari setiap respon menggunakan model polinomial: Mean, Linier, Quadratic dan Cubic. Optimasi formula pada program Design Expert $7.0^{\circledR}$ dilakukan dengan menentukan karakteristik dan pembobotan berdasarkan tingkat importance untuk masing-masing respon yang dioptimasi. Pemilihan formula optimum didasarkan oleh nilai desirability setiap formula, nilai desirability terbesar nantinya dipilih sebagai formula terbaik.

\section{Verifikasi formula pasta makaroni}

Tahap verifikasi ini dilakukan untuk melihat kesesuaian nilai aktual setiap respon dengan nilai prediksi yang disajikan.

\section{Analisis formula terpilih dan kontrol produk dari terigu}

Tahap ini dilakukan untuk melihat perbandingan kualitas produk dari aspek kimia, mikrostruktur atau penampakan serta penerimaan konsumen.

\section{Kadar abu}

Pengukuran kadar abu menggunakan metode pengabuan kering mengacu AOAC, 2005. Cawan porselin beserta tutup dikeringkan pada suhu $105^{\circ} \mathrm{C}$ selama 15 menit, lalu didinginkan dalam desikator dan ditimbang. Sampel sebanyak 2-3 g ditimbang ke dalam cawan porselin dan dibakar hingga tidak berasap. Selanjutnya, sampel diabukan di dalam tanur listrik bersuhu $550^{\circ} \mathrm{C}$ hingga proses pengabuan sempurna. Cawan yang berisi sampel tersebut didinginkan dan ditimbang hingga diperoleh bobot konstan. Penghitungan kadar abu berdasarkan rumus berikut: 


$$
\text { Kadar abu }(\% \text { bb })=\frac{\mathrm{W} 1-\mathrm{W} 2}{\mathrm{~W}} \times 100
$$

Keterangan :

$\mathrm{W}=$ bobot contoh sebelum diabukan $(\mathrm{g})$

$\mathrm{W}_{1}=$ bobot contoh + cawan setelah diabukan $(\mathrm{g})$

$\mathrm{W}_{2}=$ bobot cawan kosong $(\mathrm{g})$

\section{Kadar air}

Pengukuran kadar air dilakukan dengan metode oven (AOAC, 2005). Cawan aluminium kosong dikeringkan pada suhu $105^{\circ} \mathrm{C}$ selama 15 menit, didinginkan dalam desikator dan ditimbang. Sebanyak 1-2 g sampel pada cawan tersebut ditimbang dan dikeringkan pada oven dengan suhu $105^{\circ} \mathrm{C}$ selama lima jam. Setelah didinginkan, cawan yang berisi sampel ditimbang hingga diperoleh bobot relatif konstan.

$$
\text { Kadar air }(\% \text { bb })=\frac{(\mathrm{W}-(\mathrm{W} 1-\mathrm{W} 2)) \times 100}{\mathrm{~W}}
$$

Keterangan:

$\mathrm{W}=$ bobot contoh sebelum dikeringkan $(\mathrm{g})$

$\mathrm{W}_{1}=$ bobot contoh + cawan kering kosong $(\mathrm{g})$

$\mathrm{W}_{2}=$ bobot cawan kosong $(\mathrm{g})$

\section{Kadar lemak metode soxhlet (AOAC, 2005)}

Sebanyak 1-2 g sampel ditimbang dalam gelas piala lalu ditambahkan $30 \mathrm{~mL} \mathrm{HCl} \mathrm{25 \%} \mathrm{(Merck,}$ Germany) dan $20 \mathrm{~mL}$ air. Selanjutnya gelas piala berisi sampel dididihkan selama 15 menit dalam kondisi tertutup untuk hidrolisis. Sampel kemudian disaring menggunakan kertas saring dalam keadaan panas dan dicuci dengan air panas hingga tidak asam. Kertas saring beserta sampel dikeringkan pada suhu $105^{\circ} \mathrm{C}$. Tahap ekstraksi dilakukan dengan memasukkan kertas saring yang sudah dikeringkan ke dalam selongsong yang dialasi dengan kapas. Sampel kemudian dimasukkan ke dalam alat soxhlet yang terhubung dengan labu lemak yang telah dikeringkan dan ditimbang sebelumnya, lalu ditambahkan pelarut n-hexana (Merck, Germany) sebanyak $150 \mathrm{~mL}$. Ekstraksi dilakukan selama \pm 6 jam. Setelah tahapan ekstraksi, pelarut disuling dan ekstrak lemak dalam labu lemak dikeringkan pada suhu $105^{\circ} \mathrm{C}$ kemudian didinginkan pada desikator dan ditimbang.

Kadar lemak $\left(\mathrm{g} / 100 \mathrm{~g}\right.$ bahan basah) $=\frac{\mathrm{W}_{1}-\mathrm{W}_{2}}{\mathrm{~W}} \times 100$

Keterangan:

$\mathrm{W}=$ bobot contoh $(\mathrm{g})$

$\mathrm{W}_{1}=$ bobot labu lemak+lemak hasil ekstraksi $(\mathrm{g})$

$\mathrm{W}_{2}=$ bobot labu lemak kosong $(\mathrm{g})$

\section{Kadar protein metode Kjehdal (AOAC, 2005)}

Pengukuran kadar protein dilakukan dengan metode Kjeldahl yang terdiri dari tahap digesti, destilasi dan titrasi. Pada tahap penghancuran (digestion), sampel sebanyak $250 \mathrm{mg}$ ditimbang ke dalam labu kjeldahl, kemudian ditambahkan 1,0 0,1 $\mathrm{g} \mathrm{HgO}, 2 \pm 0,1 \mathrm{~mL} \mathrm{H}_{2} \mathrm{SO}_{4}$ (Merck, Germany) dan 2-3 butir batu didih untuk didihkan selama 1-1.5 jam hingga berwarna jernih. Setelah hasil digesti dingin, air destilata ditambahkan secara perlahan melalui dinding labu untuk melarutkan kristal yang terbentuk. Selanjutnya isi labu dipindahkan ke dalam alat destilasi dan labu dibilas 5-6 kali dengan 1-2 mL air destilata. Air cucian dipindahkan ke labu destilasi dan ditambahkan 8-10 mL larutan $60 \% \mathrm{NaOH}-5 \%$ $\mathrm{Na}_{2} \mathrm{SO}_{3}$ (Merck, Germany). Erlenmeyer yang berisi 5 $\mathrm{mL}$ larutan $\mathrm{H}_{3} \mathrm{BO}_{3}$ dan 2-4 tetes indikator red-metilen blue diletakkan di bawah kondensor, sehingga diperoleh sekitar $15 \mathrm{~mL}$ destilat dan dilanjutkan pada tahap titrasi. Titrasi dilakukan menggunakan $\mathrm{HCl} 0,1$ $\mathrm{N}$ terstandardisasi terhadap destilat yang diencerkan hingga $50 \mathrm{~mL}$, hingga terjadi perubahan warna menjadi ungu dan terukur volume $\mathrm{HCl}$ yang diperlukan. Kadar protein contoh dapat dihitung menggunakan rumus berikut:

$$
\begin{aligned}
& \% \mathrm{~N}= \\
& \frac{(\mathrm{mL} \mathrm{HCl} \text { contoh }-\mathrm{mL} \mathrm{HCl} \text { blanko) } \times \mathrm{N} \mathrm{HCl} \times 14,007}{m g \text { contoh }} \times 100
\end{aligned}
$$

Kadar protein $(\% \mathrm{bb})=\% \mathrm{~N} \times$ Faktor konversi

\section{Kadar karbohidrat by difference}

Berdasarkan metode ini kandungan karbohidrat dihitung dari hasil pengurangan angka 100 dengan presentasi komponen lain yaitu kadar abu, kadar air, kadar lemak dan kadar protein.

\section{Kadar amilosa}

Berdasarkan metode dari Faridah et al. (2014) analisis amilosa dilakukan dengan cara pembuatan kurva standar dan analisis contoh. Pembuatan kurva standar dilakukan dengan melarutkan $40 \mathrm{mg}$ amilosa murni (Sigma Aldrich, USA) ke dalam $1 \mathrm{~mL}$ etanol 95\% dan $9 \mathrm{~mL} \mathrm{NaOH} 1 \mathrm{~N}$ (Merck, Germany). Analisis contoh dilakukan dengan melarutkan 100 mg sampel dengan $1 \mathrm{~mL}$ etanol $95 \%$ dan $0 \mathrm{~mL}$ $\mathrm{NaOH} 1 \mathrm{~N}$. Tabung reaksi kemudian dipanaskan dalam air mendidih selama 10 menit hingga terbentuk gel. Setelah didinginkan, seluruh campuran dimasukkan ke dalam labu takar $100 \mathrm{~mL}$ dan ditepatkan di tanda tera dengan menggunakan air destilata. Sebanyak $5 \mathrm{~mL}$ larutan contoh dipipet ke dalam labu takar $100 \mathrm{~mL}$, ditambahkan sebanyak $1 \mathrm{~mL}$ asam asetat $1 \mathrm{~N}$ dan $2 \mathrm{~mL}$ larutan iod dan ditambahkan air destilata hingga tanda tera. Larutan didiamkan selama 20 menit kemudian nilai absorbansi diukur pada $625 \mathrm{~nm}$. 


$$
\text { Kadar amilosa }(\%)=\frac{C \times V \times F P \times 100}{W \times 1000}
$$

Keterangan :

$\mathrm{C}=$ Konsentrasi amilosa contoh dari kurva standar $(\mathrm{mg} / \mathrm{mL})$

$\mathrm{V}=$ Volume akhir contoh $(\mathrm{mL})$

$\mathrm{FP}=$ Faktor pengenceran

$\mathrm{W}=$ berat contoh $(\mathrm{mg})$

\section{Analisis organoleptik (Nadra dan Pascal, 2010)}

Analisis organoleptik dilakukan dengan menggunakan uji rating hedonik dengan 30 orang panelis tidak terlatih. Parameter yang diamati adalah rasa, warna, tekstur dan overall dengan rentang skor penilaian dari angka 1 hingga $7(1=$ sangat tidak suka dan 7 = sangat suka).

\section{Analisis scanning electron microscopy (SEM)}

Mikrostruktur sampel diamati dengan menggunakan metode SEM. Sampel dipasang pada stainleess steel specimen tubs dengan perekat. Sampel dilapis dengan emas, kemudian dimasukkan ke dalam vacum chamber. Selanjutnya, sampel yang sudah disiapkan ditembak elektron menggunakan Scanning Electron Microscopy (Zeit type Evo Ma 10, Inggris) dengan tegangan $14 \mathrm{kV}$.

\section{Analisis data}

Data kuantitatif yang diperoleh akan diuji menggunakan one way ANOVA dan apabila terdapat perbedaan akan diuji lanjut menggunakan Duncan pada taraf signifikansi $5 \%$.

\section{HASIL DAN PEMBAHASAN}

\section{Karakterisasi tepung}

Pada Tabel 3 menunjukkan hasil karakterisasi kimia tepung beras hasil penggilingan basah.
Tabel 3. Karakterisasi kimia tepung beras varietas IR42 per $100 \mathrm{~g} \mathrm{(bb)}$

\begin{tabular}{lc}
\hline \multicolumn{1}{c}{ Kriteria Uji } & Nilai \pm SD \\
\hline Kadar air & $8,34 \pm 0,07$ \\
Kadar abu & $0,29 \pm 0,00$ \\
Kadar protein & $9,03 \pm 0,02$ \\
Kadar lemak & $0,75 \pm 0,02$ \\
Kadarkarbohidrat & $81,59 \pm 0,03$ \\
bydifference & \\
Kadar amilosa & $26,57 \pm 0,25$ \\
\hline
\end{tabular}

Keterangan: Nilai (dalam numerik) disajikan sebagai nilai rataan $(n=3) \pm S D$

Menurut BSN, 2009 yang mengatur tentang syarat mutu tepung beras, kadar air (b/b) tepung beras maksimal adalah $13 \%$ dan kadar abu (b/b) maksimal $1 \%$. Hasil karakterisasi tepung beras menunjukkan bahwa tepung beras IR42 memenuhi standar mutu tepung beras yang dipersyaratkan dengan kadar air $8,34 \pm 0,07 \%$ dan kadar abu $0,29 \pm 0,00 \%$. Selain itu, tepung beras IR42 yang digunakan memiliki kandungan amilosa $26,57 \pm 0,25 \%$, sehingga dapat diklasifikasikan ke dalam beras beramilosa tinggi dengan kadar lebih dari $25 \%$ (Prasad et al., 2012).

\section{Respon optimasi}

Pengaruh proporsi antara xanthan gum dan guar gum terhadap karakteristik fisik daya serap air, pengembangan volume, dan cooking loss ditampilkan pada Gambar 1. Daya serap air menunjukkan persentase jumlah air yang dapat diserap oleh pasta dibandingkan dengan berat awal pasta. Daya serap air pasta makaroni tepung beras berkisar 103,82$139,67 \%$. Hal ini menunjukkan bahwa produk pasta beras IR42 dengan berbagai variasi rasio penggunaan xanthan gum dan guar gum memiliki parameter kualitas yang baik.

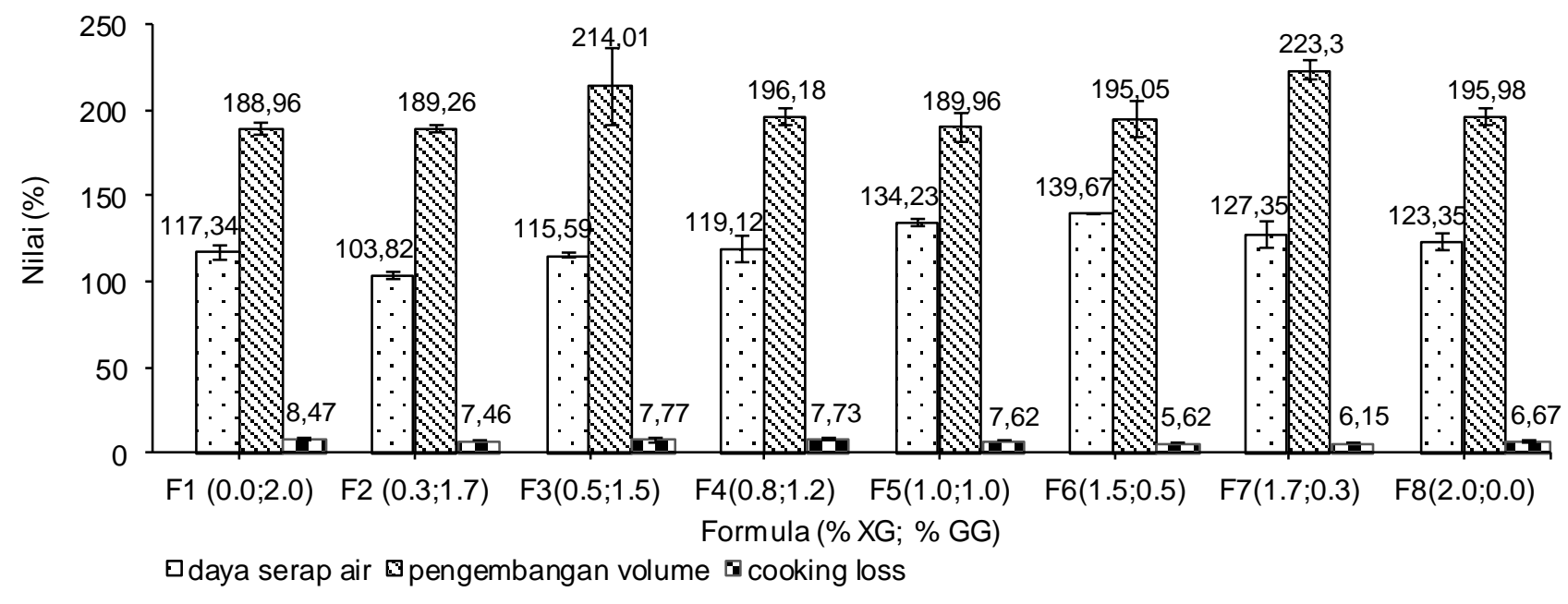

Gambar 1. Pengaruh rasio xanthan gum (XG) dan guar gum (GG) terhadap respon daya serap air, pengembangan volume dan cooking loss 
Daya serap air yang lebih dari $100 \%$ menunjukkan peningkatan berat pasta lebih dari dua kali dari berat awal. Hummel (1966) dalam Fernandez (2013) melaporkan bahwa pasta berbasis tepung terigu dengan kualitas baik akan mengalami kenaikan berat dua kali dari berat awal setelah dimasak. Sozer (2009) menambahkan bahwa gluten akan menyerap air dua kali dari berat awal dan menahannya melalui ikatan kimia yang kompleks. Berdasarkan hasil analisis fisik diketahui bahwa pasta makaroni dari tepung beras memiliki daya serap air yang tidak berbeda dengan tepung terigu $(P>0,05)$.

Analisis terhadap pengembangan volume pasta ditunjukkan oleh persentase peningkatan volume pasta masak relatif terhadap pasta mentah. Formula F3 (0,5\% XG, $1,5 \%$ GG) dan F7 (1,7\% XG dan $0,3 \%$ GG) memiliki pengembangan volume lebih besar dari $200 \%$. Formula lain memiliki pengembangan volume yang relatif sama yaitu 188-196\%. F6 memiliki nilai cooking loss terendah yaitu $5,62 \%$, artinya dalam setiap $100 \mathrm{~g}$ pasta yang dimasak akan kehilangan residu pasta sebesar 5,62 g. Apabila melihat hasil analisis terhadap seluruh formula, penambahan hidrokoloid (xanthan gum dan guar gum) pada produksi pasta makaroni dari beras IR42 memiliki cooking loss lebih rendah dibandingkan penelitian Lai (2001) yaitu 11-22\% pada pasta beras varietas GT Indica dengan penambahan emulsifier jenis GMS dan KM300.

Adhesiveness merupakan parameter yang dipengaruhi oleh kandungan amilosa dan tingkat retrogradasi pati (Yu et al., 2009). Kadar amilosa yang tinggi akan menghasilkan produk dengan tingkat adhesiveness yang rendah (Haliza et al., 2012). Rendahnya nilai adhesiveness tersebut dapat diperbaiki seiring dengan peningkatan konsentrasi hidrokoloid serta jenis hidrokoloid yang sinergis. Pengaruh antara rasio konsentrasi hidrokoloid terhadap nilai adhesiveness dari delapan formula pasta makaroni beras ditampilkan pada Gambar 2. Nilai adhesiveness akan menunjukkan tingkat kelengketan (stickiness) produk pasta. Pasta dengan kualitas baik memiliki kelengketan rendah (Susanna dan Phabasankar, 2013). Berdasarkan hasil analisis, respon adhesiveness berada pada rentang nilai 0,05 hingga $0,46 \mathrm{~mJ}$. Perbedaan komposisi gum sebagai hidrokoloid dalam kedelapan formula memberikan pengaruh signifikan terhadap kelengketan produk $(P<0,05)$. Nilai adhesiveness produk menunjukkan perbedaan yang nyata di antara kedelapan formula yang diuji $(P<0,05)$. Nilai Adhesivenes tertinggi terdapat pada pasta $\mathrm{F} 1$ ( $0 \% \mathrm{XG}, 2 \% \mathrm{GG})$ dengan nilai $0,46 \mathrm{~mJ}$ dan nilai terendah terdapat pada pasta F8 $(2 \%$ XG, $0 \%$ GG) dengan nilai 0,05 mJ. Springiness merupakan parameter yang menunjukkan kemampuan suatu bahan untuk kembali ke posisi awal dari tingkat kompresi pada gigitan pertama hingga ke gigitan kedua (Haliza et al., 2012). Berdasarkan hasil analisis terhadap delapan formula pasta makaroni, nilai respon springiness memiliki rentang nilai antara 2,03 $\mathrm{mm}$ hingga $5,83 \mathrm{~mm}$ (Gambar 3). Nilai springiness tertinggi ditunjukkan oleh formula F8 dengan kombinasi rasio penggunaan xanthan gum $2 \%$ dan guar gum $0 \%$, sedangkan hasil terendah ditunjukkan pada formula F6 yaitu penambahan $1,5 \%$ xanthan gum dan $0,5 \%$ guar gum.

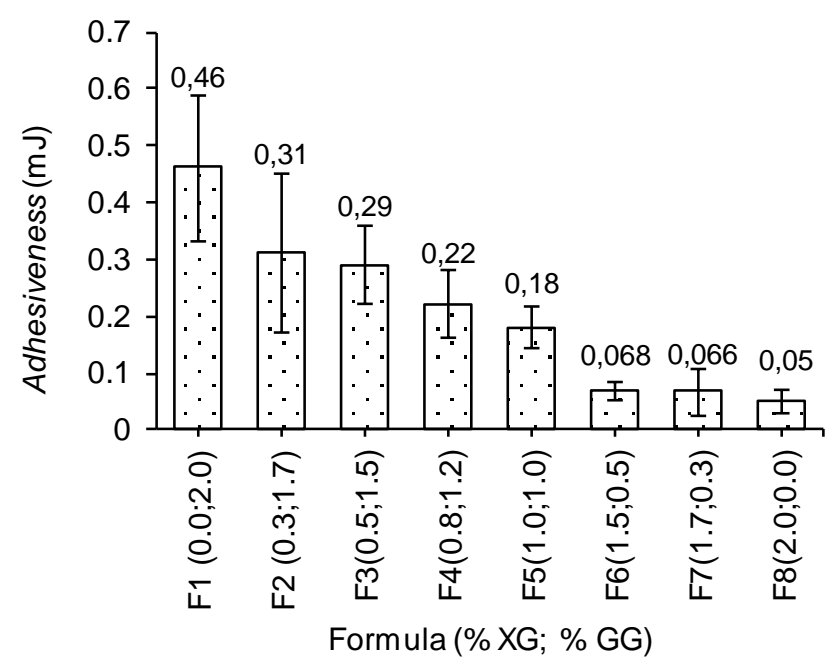

Gambar 2. Pengaruh rasio xanthan gum (XG) dan guar gum (GG) terhadap respon adhesiveness

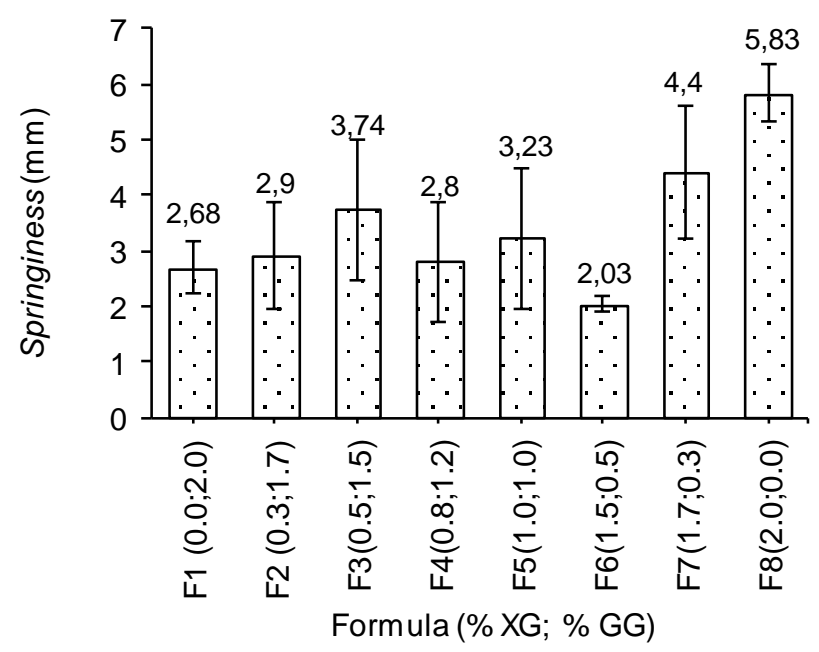

Gambar 3. Pengaruh rasio xanthan gum (XG) dan guar gum (GG) terhadap respon springiness

Penampakan warna produk pasta dinyatakan oleh nilai lightness, chroma, dan hue seperti ditunjukkan pada Gambar 4 dan 5. Kedelapan formula produk pasta beras memiliki nilai hue pada kisaran nilai $96,57^{\circ}-102,00^{\circ}$. Intensitas nilai tersebut menunjukkan produk pasta berwarna kromatis kuning kehijauan. Chroma yang menunjukkan intensitas 
hue memiliki rentang nilai 0-60. Nilai chroma yang tinggi menunjukkan intensitas hue yang tinggi sehingga warna produk akan cerah dan mencolok sedangkan jika nilai chroma rendah warna produk akan redup (Andarwulan et al., 2011). Rentang nilai kedelapan formula menunjukkan nilai chroma 5,610,38, mengindikasikan intensitas warna hue produk rendah sehingga warna yang dihasilkan redup. Formula uji 1-8 memiliki rentang nilai lightness antara 86,16 hingga 90,29.

Berdasarkan hasil uji terhadap delapan respon optimasi diketahui bahwa perbedaan rasio xanthan gum dan guar gum dengan total penambahan $2 \%$ berpengaruh nyata terhadap respon cooking loss, adhesiveness, springiness dan hue $(P<0,05)$ serta tidak berpengaruh nyata terhadap respon daya serap air, hue, chroma dan lightness $(P>0,05)$. Kedelapan produk yang dihasilkan menunjukkan penampakan visual yang tak berbeda nyata yaitu putih.

\section{Respon optimasi}

Untuk menghasilkan formula optimum pasta makaroni, kedelapan respon hasil analisis fisik dioptimasi. Hal ini karena karakteristik fisik suatu produk berpengaruh terhadap penerimaan konsumen (Susanna dan Phrabasankar, 2013). Pasta dengan kualitas fisik yang baik memiliki cooking loss rendah (Fernandez et al., 2013), kelengketan rendah dan tekstur kompak (Susanna dan Phrabasankar, 2013; Fernandez et al., 2013), daya serap air dua kali dari berat awal (Sozer, 2009) dan peningkatan dimensi pasta masak relatif terhadap pasta mentah (Lucisano et al., 2012). Pasta dengan daya serap air tinggi menyebabkan air berpenetrasi ke bagian dalam struktur pasta, sehingga kelengketan pasta rendah dan volume mengembang. Struktur pasta yang elastis dan kelengketan yang rendah pada permukaannya mengurangi terjadinya residu pasta yang hilang selama pemasakan.

Pemilihan formula optimum didasarkan pada nilai desirability yang dihasilkan. Nilai desirability yang mendekati nilai 1 menunjukkan bahwa formula tersebut memiliki kriteria-kriteria respon sesuai nilai yang ditargetkan. Nilai desirability delapan formula yang diuji disajikan di Gambar 6. Berdasarkan grafik tersebut diketahui bahwa nilai desirability tertinggi sebesar 0,798 yang diperoleh pada produk dengan penambahan xanthan gum sebanyak $2 \%$. Berdasarkan data nilai desirability yang dihasilkan dapat diketahui bahwa peningkatan jumlah xanthan gum dan penurunan jumlah guar gum yang ditambahkan dapat meningkatkan nilai desirability dari produk pasta beras ini. Pengamatan terhadap mikrostruktur pasta beras menggunakan SEM menunjukkan xanthan gum melapisi sebagian besar granula pati
(Chaisawang dan Suphantharika, 2006) yang membatasi pembengkakan granula dan peningkatan viskositas selama pasting. Xanthan gum meningkatkan ikatan antar granula pati (Abdulmola et al., 1996) sehingga mendukung proses penyusunan struktur yang kokoh. Proses inilah yang menjelaskan bahwa formula pasta makaroni dari beras beramilosa tinggi dengan total penambahan xanthan gum sebesar $2 \%$ akan menghasilkan karak-teristik fisik (cooking loss, adhesiveness springiness dan hue) yang lebih baik. Produk pasta makaroni beras yang dihasilkan dari optimasi serta tepung beras IR 64 dapat dilihat pada Gambar 9 dan 10.

\section{Verifikasi formula terpilih}

Proses verifikasi dilakukan untuk menguji kesesuaian nilai aktual dengan nilai prediksi dari program. Kesesuaian data terjadi jika hasil verifikasi masuk ke dalam rentang nilai prediksi, baik $\mathrm{Cl}$ ataupun PI. Berdasarkan hasil verifikasi yang disajikan pada Tabel 4 dapat diketahui bahwa nilai daya serap air dan chroma tergolong ke dalam rentang nilai PI. Nilai uji cooking loss, derajat pengembangan, springiness, lightness dan hue tergolong ke dalam rentang nilai $\mathrm{Cl}$ serta adhesiveness tergolong ke dalam hasil prediksi. Hasil uji verifikasi formula terpilih ini menunjukkan bahwa hasil aktual analisis respon optimasi sesuai dengan hasil pengolahan data prediksi yang dianalisis oleh program Design Expert 7.0. Kesesuaian data hasil verifikasi membuktikan bahwa formula pasta makaroni dengan penambahan xanthan gum $2 \%$ merupakan formula optimum pasta makaroni dari beras beramilosa tinggi.

Tabel 4. Hasil tahapan verifikasi dan prediksi setiap respon

\begin{tabular}{lcccc}
\hline Respon & Prediksi & $\begin{array}{c}\text { Hasil } \\
\text { Veri- } \\
\text { fikasi }\end{array}$ & $\begin{array}{c}\text { Con- } \\
\text { fidental } \\
\text { Interval } \\
95 \%\end{array}$ & $\begin{array}{c}\text { Prediction } \\
\text { Interval } \\
95 \%\end{array}$ \\
\hline Daya & 122,78 & $131,50 \pm$ & $115,50-$ & $95,53-$ \\
serap air & & 1,94 & 130,06 & 150,03 \\
Cooking & 6,39 & $6,05 \pm$ & $5,76-$ & $4,87-$ \\
loss & & 0,47 & 7,02 & 7,91 \\
Pengem- & 196,35 & $189,73 \pm$ & $188,67-$ & $167,60-$ \\
bangan & & 1,39 & 204,03 & 225,10 \\
Adhesi- & 0,0083 & $0,0080 \pm$ & $0-$ & $0-$ \\
veness & & 0,0050 & 0,1625 & 0,3768 \\
Springi- & 5,00 & $4,55 \pm$ & $3,69-$ & $1,86-$ \\
ness & & 1,91 & 6,32 & 8,15 \\
Lightness & 87,58 & $86,37 \pm$ & $86,30-$ & $82,79-$ \\
& & 0,30 & 88,86 & 92,36 \\
Hue & 100,603 & $101,95 \pm$ & $98,48-$ & $96,27-$ \\
& & 0,97 & 102,73 & 104,94 \\
Chroma & 7,27 & $5,27 \pm$ & $6,27-$ & $3,54-$ \\
& & 0,28 & 8,27 & 11,00 \\
\hline
\end{tabular}




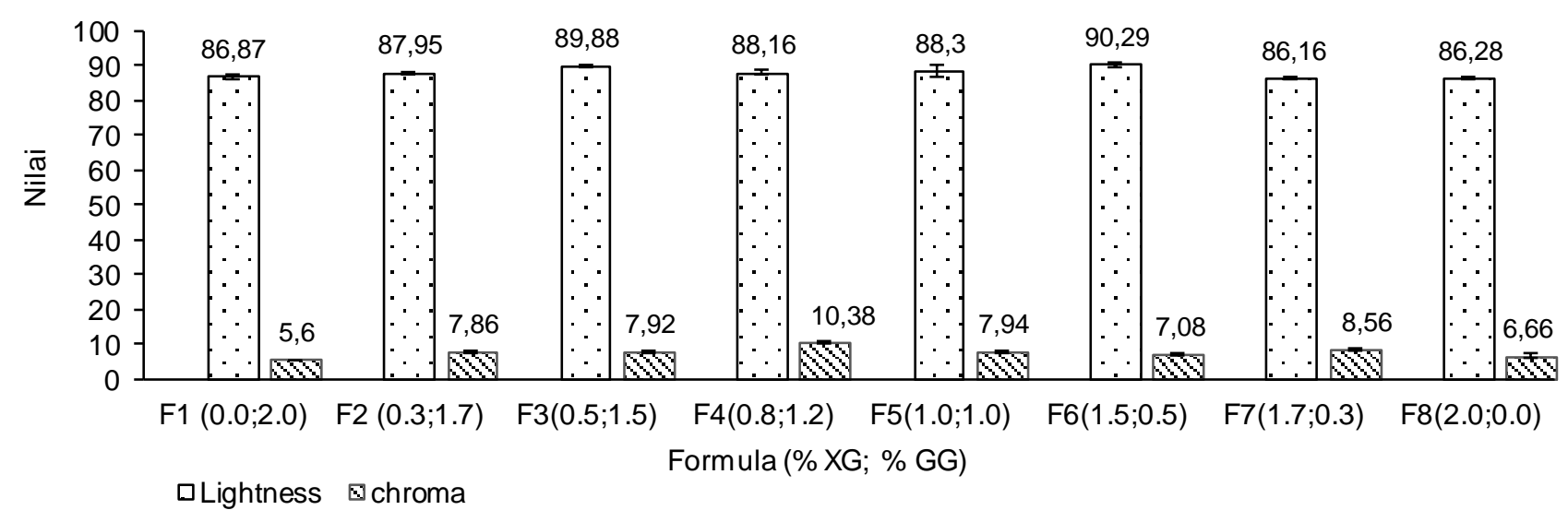

Gambar 4. Pengaruh rasio xanthan gum (XG) dan guar gum (GG) terhadap respon lightness dan chroma

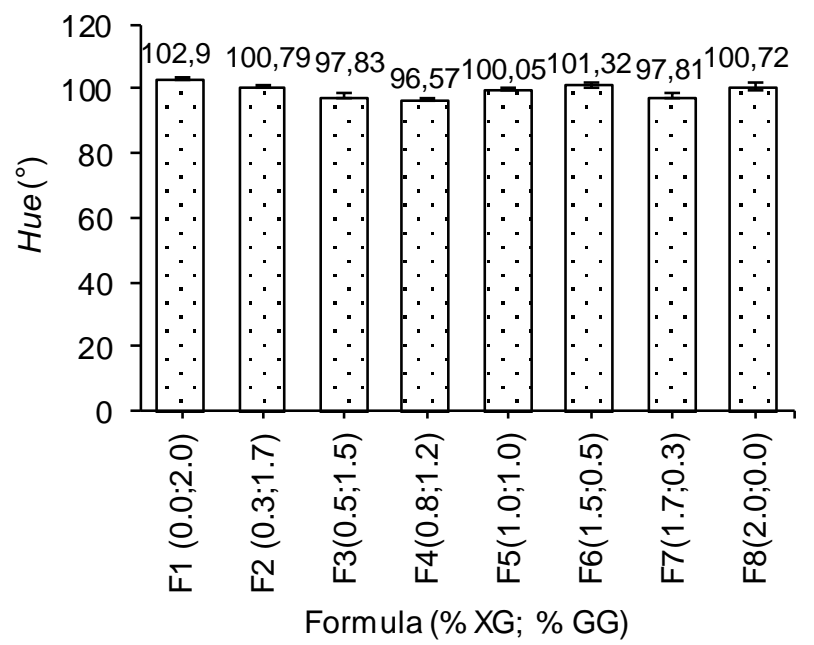

Gambar 5. Pengaruh rasio xanthan gum (XG) dan guar gum $(\mathrm{GG})$ terhadap respon hue

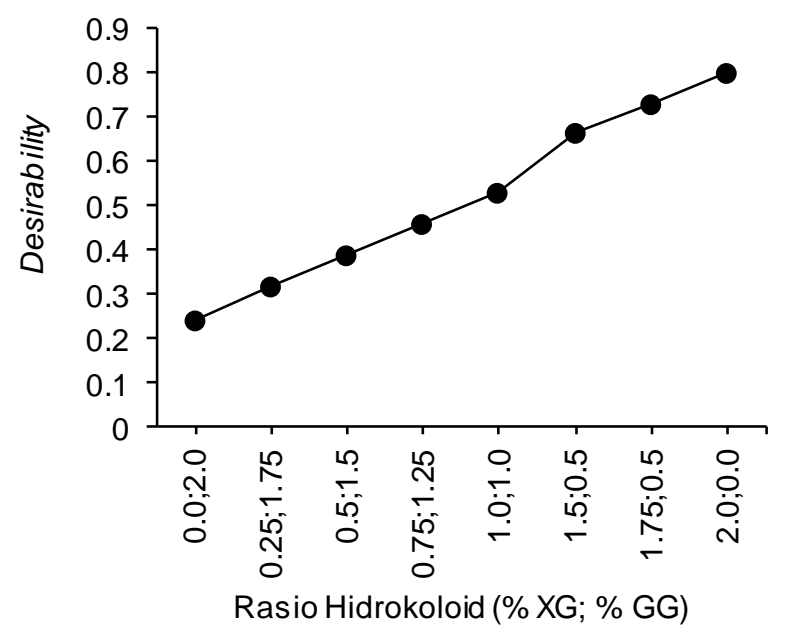

Gambar 6. Grafik nilai desirability delapan formula produk pasta makaroni beras

\section{Karakteristik organoleptik formula terpilih dan produk kontrol}

Analisis organoleptik dilakukan untuk mengetahui tingkat penerimaan konsumen terhadap formula optimum pasta makaroni dari beras, dibandingkan dengan pasta dari terigu. Uji rating hedonik dilakukan menggunakan 30 panelis tidak terlatih dengan rentang skor dari 1-7 (sangat tidak suka-sangat suka) dan aspek uji: warna, rasa, aroma, tekstur dan overall. Hasil uji organoleptik ditampilkan pada Gambar 7. Pasta makaroni terigu memiliki keunggulan dari aspek warna dan aroma, namun secara keseluruhan tidak ada perbedaan nyata signifikan antara pasta makaroni yang terbuat dari terigu dan beras $(P>0,05)$. Hal ini menunjukkan bahwa tepung beras dapat dijadikan sebagai salah satu alternatif bahan untuk membuat produk pasta bebas gluten.

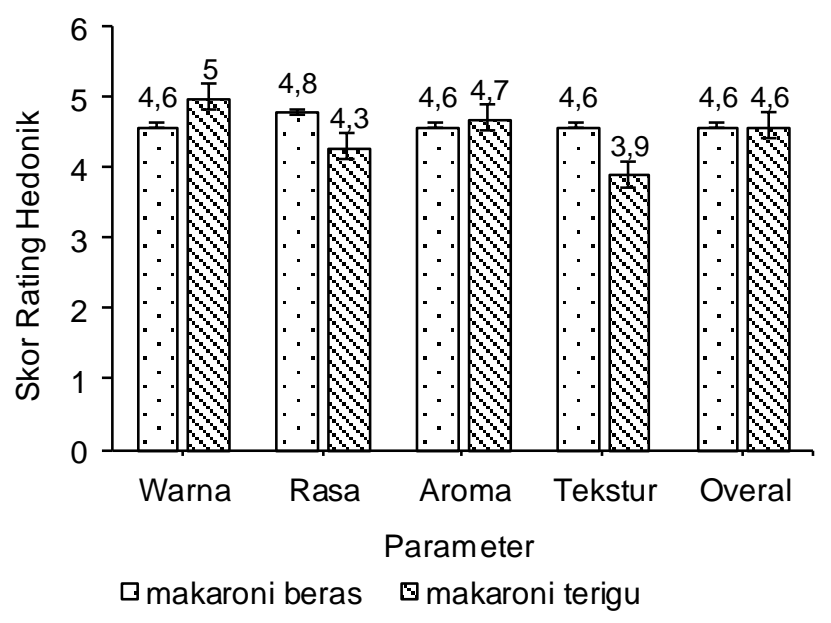

Gambar 7. Grafik analisis organoleptik (rating hedonik) produk pasta makaroni 


\section{Proksimat dan kadar amilosa formula terpilih dan produk kontrol}

Perbedaan kandungan gizi pada pasta makaroni beras dan terigu dapat dilihat dengan membandingkan hasil analisis proksimat (kimia) kedua jenis pasta seperti ditampilkan pada Tabel 5. Secara umum, nilai kandungan gizi produk pasta makaroni beras hampir menyerupai pasta makaroni terigu. Kadar lemak makaroni terigu 1.5 kali lebih besar dibandingkan dengan makaroni beras. Kadar protein makaroni terigu $(18,41 \pm 0,28 \%)$ lebih tinggi dibandingkan makaroni beras $(12,05 \pm 0,10 \%)$. Hal ini karena bahan utama yang digunakan berbeda, tepung beras IR42 mengandung protein 9,03\%, sedangkan kadar protein tepung terigu tinggi protein pada kisaran 11-13\%. Selain itu, telur yang ditambahkan dalam proses pembuatan produk tidak hanya berpengaruh dalam peningkatan kualitas tekstur produk, namun juga meningkatkan kadar protein kedua produk pasta. Kadar abu dan kadar air produk pasta beras lebih tinggi dibandingkan dengan pasta terigu. Kadar amilosa makaroni beras $(20,49 \pm 0,24 \%)$ lebih besar dibandingkan dengan

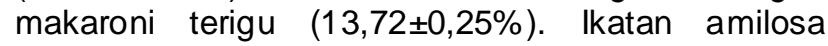
dengan bahan lain menjadi salah satu faktor yang menentukan struktur fisik pasta makaroni.

Tabel 5. Hasil analisis proksimat dan kadar amilosa makaroni terigu dan makaroni beras (\% $\mathrm{b} / \mathrm{b})$

\begin{tabular}{lcc}
\multicolumn{1}{c}{$\mathrm{b} / \mathrm{b})$} & Makaroni & Makaroni \\
Kriteria Uji & $\begin{array}{c}\text { Beras (\%) } \\
\pm \mathrm{SD}\end{array}$ & $\begin{array}{c}\text { Terigu (\%) } \\
\pm \mathrm{SD}\end{array}$ \\
\hline Kadarair & $9,84 \pm 0,04$ & $7,08 \pm 0,06$ \\
Kadarabu & $1,65 \pm 0,00$ & $1,22 \pm 0,00$ \\
Kadar protein & $12,05 \pm 0,10$ & $18,41 \pm 0,28$ \\
Kadar lemak & $1,41 \pm 0,02$ & $2,33 \pm 0,01$ \\
Kadar karbohidrat & $75,05 \pm 0,12$ & $70,95 \pm 0,22$ \\
Kadaramilosa & $20,49 \pm 0,24$ & $13,72 \pm 0,25$ \\
\hline
\end{tabular}

\section{Analisis scanning electron microscopy (SEM)}

Analisis SEM dilakukan untuk mengamati mikrostruktur pati dan ukuran pori terhadap produk pasta makaroni beras terpilih dan pasta terigu. Visualisasi pengamatan mikrostruktur pasta beras dan terigu dengan perbesaran $1000 \mathrm{X}$ dapat diamati di Gambar 8. Hasil pengamatan menunjukkan bahwa pasta beras dan terigu memiliki perbedaan struktur visual mikro karena perbedaan bahan dasar serealia yang digunakan. Ukuran pori pasta makaroni beras $33,49 \mu \mathrm{m}$, sedangkan makaroni terigu 21,66 $\mu \mathrm{m}$. Selain itu, struktur visual pati pada makaroni beras kurang teratur dan lebih besar dibandingkan makaroni terigu. Implikasi yang dihasilkan dari pengamatan ini yaitu adanya perbedaan struktur pasta konvensional dari terigu dan pasta bebas gluten dari tepung beras. Struktur pasta makaroni terigu ditentukan oleh komposisi gluten dengan karakteristik liat dan elastis, sementara pasta beras memiliki struktur yang terbentuk oleh gelatinisasi pati. Lai (2001) dan Larossa et al. (2015) melaporkan bahwa penggunaan GMS dan mengatur waktu pemasakan pada pasta beras dapat mempengaruhi kualitas masak.

A

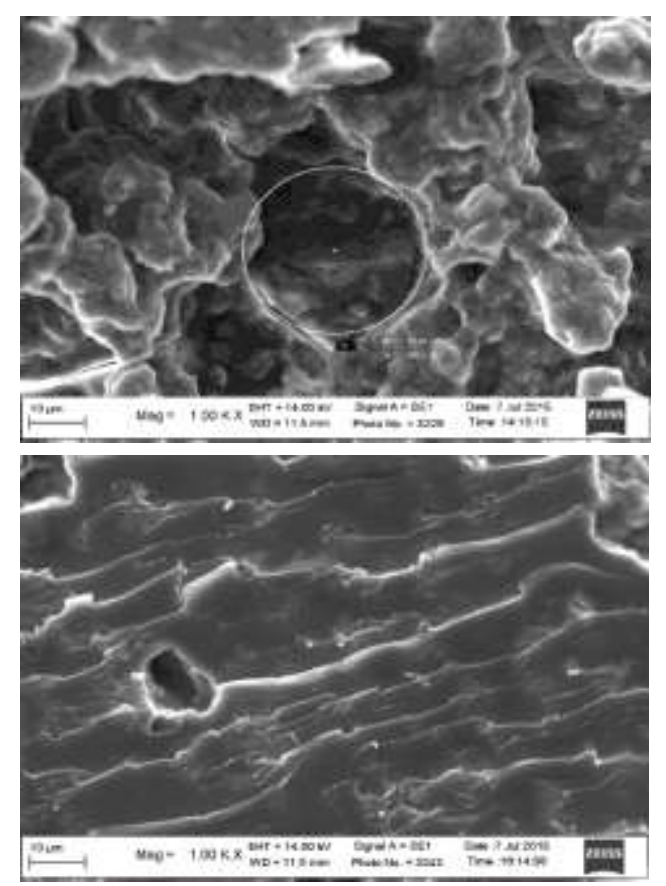

B

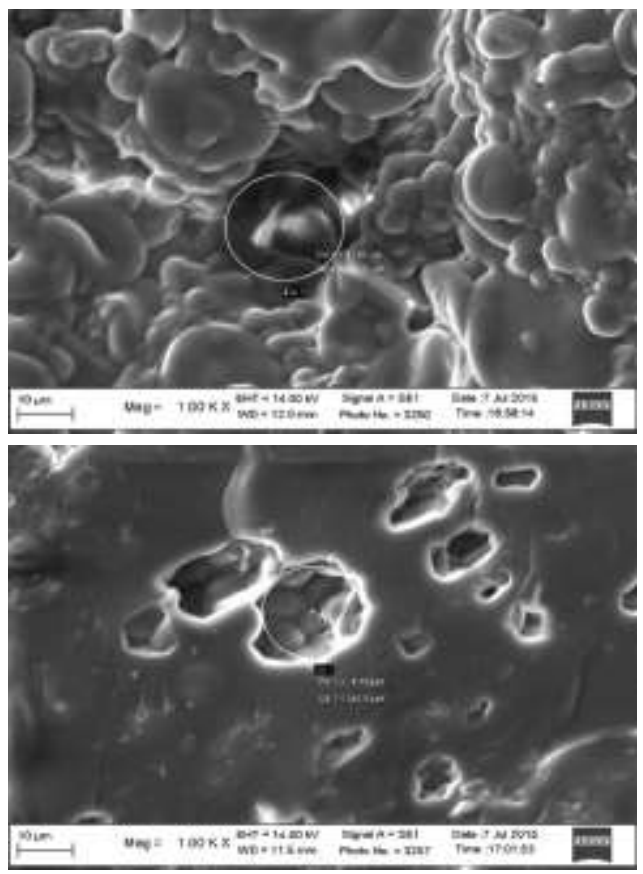

Gambar 8. Hasil pengamatan Scanning electron microscopy (SEM) (a) Makaroni beras (b) Makaroni terigu, (atas) permukaan luar, (bawah) sayatan dalam 


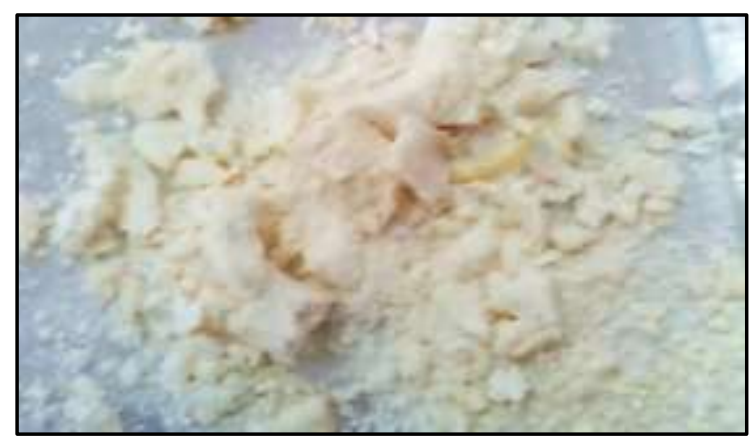

Gambar 9. Tepung beras IR 64 hasil penepungan basah

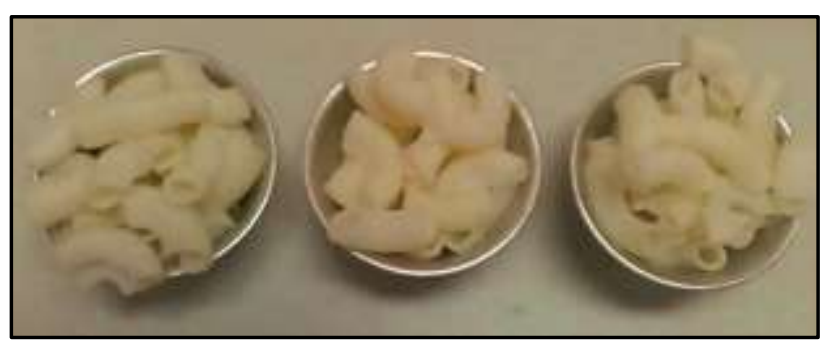

Gambar 10. Produk pasta makaroni dari tepung beras

\section{KESIMPULAN}

Kombinasi penggunaan xanthan gum dan guar gum sebagai hidrokoloid sebesar $2 \%$ berpengaruh signifikan $(P<0,05)$ terhadap karakteristik fisik pasta makaroni yaitu tekstur (springiness dan adhesiveness), cooking loss dan warna (hue), tetapi tidak memberikan pengaruh signifikan $(P>0,05)$ terhadap daya serap air, pengembangan volume, chroma dan lightness pada taraf 5\%. Optimasi formula pasta makaroni dengan basis $100 \%$ tepung beras varietas IR42 menghasilkan formula kombinasi hidrokoloid optimum ( $2 \%$ xanthan gum dan $0 \%$ guar gum) dengan nilai desirability 0,798 yang secara organoleptik diterima oleh panelis.

\section{UCAPAN TERIMAKASIH}

Penulis mengucapkan terima kasih kepada Balai Besar Penelitian dan Pengembangan Pasca Panen Pertanian, Bogor yang telah mendukung pelaksanaan penelitian ini melalui DIPABB Pascapanen TA 2015 No. 041.

\section{DAFTAR PUSTAKA}

Abdulmola NA, Hember MWN, Richardson RK, Morris ER. 1996. Effect of xanthan on small deformation rheology of crosslinked and uncroslinked waxy maize starch. Carbohyd Polym 31: 65-78. DOI: 10.1016/S01448617(96)000653.

Andarwulan N, Kusnandar F, Herawati D. 2011. Analisis Pangan. 226-248. Dian Rakyat, Jakarta, Indonesia.

[AACC] American Association of Cereal Chemist. 2000. Approved methods of the AACC (10th ed.). Minnesota (US): American Association of Cereal Chemists International.

[AOAC] Association of Official Analytical Chemistry. 2005. Official Method of Analysis. Washington DC (US): Association of Official Analytical Chemistry.

[BSN] Badan Standarisasi Nasional. 2009. SNI 3549-2009: Syarat Mutu Tepung Beras. Jakarta (ID). Badan Standarisasi Nasional.

Cabrera-Chavez F, De La Barca AMC, Islas-Rubio AR, Marti A, Marengo M, Pagani MA, Bonomi F, Lametti S. 2012. Molecular rearrangements in extrusion processes for the production of amaranth-enriched, gluten-free rice pasta. LWTFood Sci Technol 47: 421-426. DOI: 10.1016/j. Iwt.2012.01.040

Chais awang M, Suphantharika M. 2006. Pasting and rheological properties of native and anionic tapioca starches as modiffied by guar gum and xanthan gum. Food Hydrocolloid 20: 641-649. DOI: 10.1016/j.foodhyd.2005.06.003.

Faridah DN, Herawati D, Kusumaningrum HD. 2014. Penuntun Praktikum Analisis Pangan. 79-80. Departemen IImu dan Teknologi Pangan IPB, Bogor, Indonesia.

Fernanda AF, Manoel SS, Flavio AS, Maria VEG, Luciana RFS. 2013. Microstructure, texture and colour of gluten-free pasta made with amaranth flour, cassava starch and cassava bagasse. LWT-Food Sci Technol 54: 132-138. DOI: 10.1016/j.Iwt.2013.04.020.

Fernandez MS, Sehn GA, Leoro MGV, Chang YK, Steel CJ. 2013. Effect of adding unconventional raw material on the technologies properties of rice fresh pasta. Food Sci Tecnol 33: 257-264. DOI: 10.1590/S0101-20612013005000041. 
Haliza W, Kailaku SI, Yuliani S. 2012. Penggunaan mixture response surface methodology pada optimasi formula brownies berbasis tepung talas banten (Xanthosoma undiphes $\mathrm{K}$ Koch) sebagai alternatif pangan sumber serat. $J$ Pascapanen 9: 96-106.

Herrero-Hernandez JA, Frutos MJ. 2015. Influence of rutin and ascorbic acid in colour, plum anthocyanins and antioxidant capacity stability on model juices. Food Chem 173: 495-500. DOI: 10.1016/j.foodchem.2014.10.059.

Puspasari K. 2007. Aplikasi Teknologi dan Bahan Tambahan Pangan untuk Meningkatkan Umur Simpan Mie Basah Matang. [Skripsi]. Bogor (ID): Fakultas Teknologi Pertanian, Institut Pertanian Bogor.

Lai HM. 2001. Effect of rice properties and emulsifier on the quality of rice pasta. Journal of the science of food and agriculture $\mathrm{J}$ Sci Food Agri 82: 203-216. DOI: 10.1002/jsfa.1019.

Larossa V, Lorenzo G, Zaritzky N, Califano A. 2015. Dynamic rheological analysis of gluten free pasta as affected by composition and cooking time. J Food Eng 160: 11-18. DOI: 10.1016/j.j foodeng.2015.03.019.

Lucisano M, Cappa C, Fongaro L, Mariotti M. 2012. Characterisation of gluten-free pasta through conventional and innovative method: evaluation of the cooking behaviour. J Cereal Sci 56: 667675. DOI: 10.1016/j.jcs.2012.08.014.

Marti A, Paggani MA. 2013. What can play the role of gluten in gluten free pasta?. Trends Food Sci Technol 31: 63-71. DOI: 10.1016/j.tifs.2013.03. 001.

Mirhosseini H, Rasyid NFA, Amid BT, Cheong MK, Zulkurnain M. 2015. Effect of partial replacement of corn flour with durian seed flour and pumpkin flour on cooking yield, texture properties and sensory atributes of gluten free pasta. LWT-Food Sci Technol 63: 184-190. DOI: 10.1016/j.Iwt.2015.03.078.

Nadra M, Pascal S. 2010. The right number of consumers to be enrolled in a liking test strongly depends on the level of sensory complexity among product [http://www.senso metric.org/resources/documents/2010/meeting/ presentations /033-047-mammasse_2010.pdf]. [22 Agustus 2014].

Prasad K, Sing Y, Anil A. 2012. Effects of grinding method on the characeristics of Pusa 1121 rice flour. J Trop Agric Food Sci 40: 193-201.

Raina CS, Singh S, Bawa AS, Saxena DC. 2005. Textural characteristics of pasta made from rice flour supplemented with protein and hydrocolloids. J Texture Studies 36: 402-420. DOI: 10.1111/j.1745-4603.2005.00024.x.

Silva E, Birkenhake M, Scholten E, Sagis LMC, der Linden EV. 2013. Controlling rheology and structure of sweet potato starch noodles with high broccoli powder content by hidrocolloids. Food Hydrocolloid 30: 42-52. DOI: 10.1016/j. foodhyd.2012.05.002.

Sozer N. 2009. Rheological properties of rice pasta dough supplemented with proteins and gums. Food Hydrocolloid 23: 849-855. DOI: 10.1016/ j.foodhyd.2008.03.016.

Susanna S, Phrabasankar P. 2013. A study development of gluten free pasta and its bichemical and immunological validation. LWTFood Sci Technol 50: 613-621. DOI: 10.1016/j. Iwt.2012.07.040.

Tong LT, Gao X, Lin L, Liu Y, Zhong K, Liu L, Zhou X, Wang L, Zhou S. 2015. Effect of semidry flour milling on the quality attributes of rice flour and rice nooddle in China. J Cereal Sci 62: 4549. DOI: 10.1016/j.jcs.2014.12.007.

Wahyudi. 2012. Optimasi Formula Produk Ekstrusi Pasta Makaroni dari Tepung Sukun (Artocarpus Altilis) dengan Metode Desain Campuran guar gum (Mixture Design). [Skripsi]. Bogor [ID]: Fakultas Teknologi Pertanian, Institut Pertanian Bogor.

Yalcin S, Basman A. 2008. Effect of gelatinisation level, gum and transglutaminase on the quality characteristics of rice noodle. J Food Sci Tech 43. 1637 1644. DO1: 10.1111/j.13652621.2097. $01674 x$

Yu S, Ma Y, Sun DW. 2009. Impact of amylose content on starch retrogradation and texture of cooked milled rice during storage. J Cereal Sci 50:139-144. DOI: 10.1016/j.jcs.2009.04.003. 